Irish Math. Soc. Bulletin

Number 87, Summer 2021, 15-17

ISSN 0791-5578

\title{
Brian Hughes Murdoch (1930-2020)
}

\author{
ELIZABETH OLDHAM
}

Brian Murdoch, who died on 9 December 2020 at the age of 90, spent most of his long mathematical career in Trinity College Dublin. As Erasmus Smith's Professor of Mathematics from 1966 to 1989, he contributed greatly to the growth and diversification of the School of Mathematics, and he made many other contributions to mathematical education. My own path crossed his in several ways, and those personal experiences have inevitably shaped this obituary. I am grateful to other people for helping me to flesh out aspects of Brian's life with which I was less familiar.

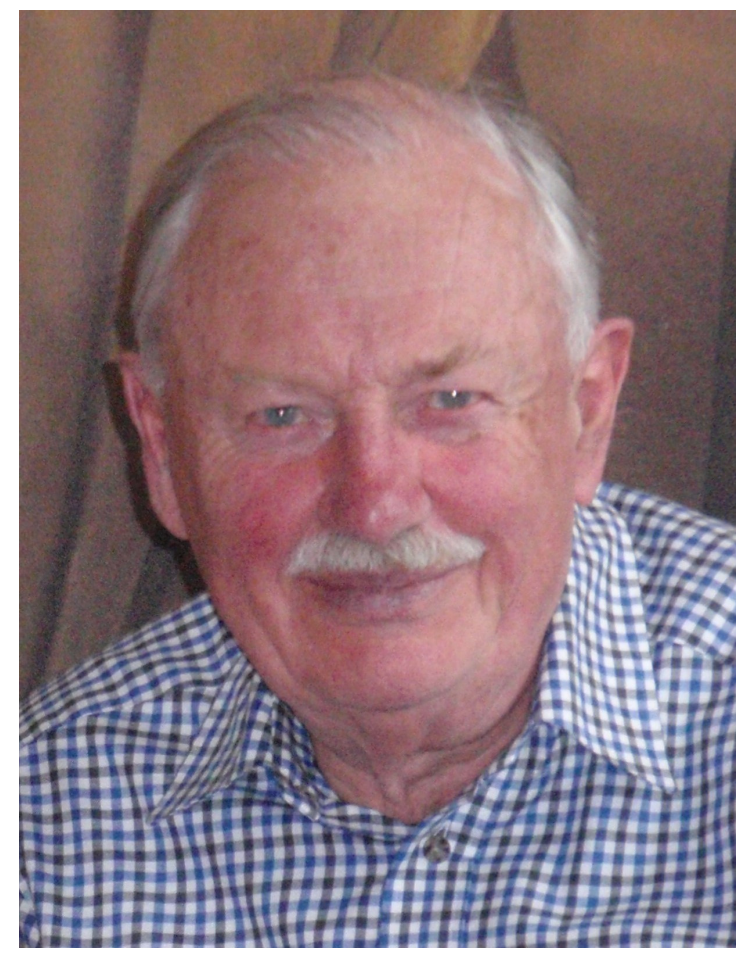

Brian was born in England on 3 April 1930, but he grew up in Dublin. As a primary school pupil, he attended Kingstown School in Dun Laoghaire; he went on to Newtown School in Waterford, and later to the High School in Dublin. In 1947, he entered the School of Mathematics in Trinity, the place to which so much of his life was devoted. He was an outstanding student. This was reflected, for example, in his being awarded a Foundation Scholarship during his first undergraduate year. (Scholars of Trinity are selected on the basis of a special examination, typically taken during students' second of the four undergraduate years; in times past, some very able students achieved "Schol" in their first year.) A further mark of his ability is that, after graduating in 1951 with a Gold Medal, he went to Princeton and studied with William Feller, writing his PhD

2020 Mathematics Subject Classification. 01A70.

Key words and phrases. Brian Murdoch.

Received on 1-6-2021.

(C)2021 Irish Mathematical Society 
dissertation on preharmonic functions. Following that, he held posts at what is now Newcastle University and at Queen's University Belfast; he then returned to his alma mater as a Junior Lecturer in 1957. The rest of his career was spent in Trinity. Over the years, he lectured on various aspects of pure mathematics, notably analysis, probability and geometry. Among the topics addressed in his published papers were preharmonic functions and random walks. He gave much time and thought to his teaching and examining, and former students remember his kind and supportive approach. (I was one such student, and I recall him telling us, when we were preparing for Schol, how he worked on his examination papers - which, when drafts were revisited, sometimes looked too easy, so he would lengthen them or insert extra challenges. We decided that he had worked very diligently that year on his Schol paper, which was exceptionally long; however, it became obvious that he took this into account punctiliously when marking our scripts.) He was elected a Fellow of the College in 1965 - at the end of my own time as a mathematics undergraduate - and became Erasmus Smith's Professor of Mathematics in spring 1966, holding that post until his retirement in 1989.

The hallmark of Brian's long period in the chair was dedicated service. When first appointed, he brought welcome stability after each of his two predecessors had come and gone within a couple of years. In autumn 1966, he was joined in the School of Mathematics by David Spearman, who had been appointed as University Professor of Natural Philosophy. Working as a team, they transformed the School of Mathematics from one that focused on the development of a small number of outstanding mathematicians to one that was more accessible and had a wider vision: producing considerably more graduates - many of whom who would take their sound mathematical knowledge productively into aspects of life other than academic - while still catering for specifically dedicated mathematicians. The programme was broadened by giving students access to modules in computer science and statistics. A further initiative was the inception of joint degrees in theoretical physics, in mathematics and economics, and in mathematics and philosophy. These were pioneering individually designed courses which were introduced long before "2-subject Moderatorships" were adopted into the University curriculum.

Brian was a member of the Religious Society of Friends (Quakers), and his Quaker principles underpinned his life. This was reflected, not only in his selfless dedication to the School of Mathematics and its students, but also in his leadership style - he strove tirelessly for consensus - and in his work for various bodies outside the college at local and national level. He served on the management committees of Rathgar Junior School and Newtown School, both of which are Quaker schools: founded by Quakers and providing a Quaker ethos, while being open to students of all religions and none. Brian also represented Quakers on the Secondary Education Committee, the body established in 1968 to administer the "Protestant Block Grant Scheme" agreed with the Department of Education when free secondary education was introduced. (The scheme assists children of the Protestant community in accessing post-primary education in a school that accords with their faith tradition, and was devised as a means of extending free education to groups that would otherwise be unable to benefit suitably.)

Some of Brian's contributions to the world of school education were more specifically concerned with mathematics. A personal reminiscence dates back to my own early days in the Trinity School of Education, when the uptake of post-primary education in Ireland was expanding at the same time as the School of Mathematics was developing and diversifying as described above. Brian told me of the developments and identified the potential for producing more specialist teachers of mathematics. He gave much as an individual also. For years, representing Trinity, he worked with the Department of Education in checking Leaving Certificate papers. He played a role too for the National 
Council for Curriculum and Assessment; he was a member of the Course Committee for Leaving Certificate Mathematics that drew up the courses introduced in the 1990s, making inputs especially with regard to probability. I served as Education Officer to that committee, and so had the pleasure of working alongside Brian and recognising at first hand his emphasis on seeking consensus. The other university mathematician on the committee was Paddy Barry, sadly also recently deceased; the two third-level representatives were notable contributors to the development of the courses. Brian was also actively engaged with the Young Scientist Exhibition, which has done so much to provide a stimulus for creative student work in the STEM area.

Brian's interests outside mathematics included travel and camping, initially on his own but later with his wife Winifred (Winnie), née Bewley. Subsequently, family holidays were often spent by the sea in Co. Galway and in France. He enjoyed classical music, and supported the Choral Society concerts in Trinity. Former students remember another aspect of his support for college activities; he was the contact for obtaining Bewley's brack and buns, greatly enjoyed features at the Dublin University Mathematical Society's annual Opening Meetings! Brian was a kind and friendly man and is fondly remembered by his colleagues. He is survived by Winnie, their children Hazel, Peter and Fiona, and grandchildren Amy, Zoe, Niamh, Katie, Lucy and Ruari.

My thanks are due to several people who helped in the production of this obituary, in particular to Winnie Murdoch, David Spearman, David Malone and Colm Mulcahy.

\section{Mathematical Publications By B.H. Murdoch}

[1] B.H. Murdoch, Preharmonic Functions, PhD Thesis, Princeton University, 1954. MR2612166

[2] A.C.Allen and B.H.Murdoch, A note on preharmonic functions, Proc. Amer. Math. Soc. 4 (1953), 842-852. MR0060650

[3] B.H. Murdoch, A theorem on harmonic functions, J. London Math. Soc. 39 (1964), 581-588. MR0168785

[4] _ A note on well-distributed sequences, Canadian J. Math. 17 (1965), 808-810. MR0180542

[5] __ Some theorems on preharmonic functions, J. London Math. Soc. 40 (1965), 407-417. MR0183893

[6] _ Rates of growth of preharmonic functions, J. London Math. Soc. 40 (1965 ), 605-618. MR0183894

[7] _ , M-distributed sequences, Proc. Roy. Irish Acad. Sect. A 64 (1966), 143-161. MR0219688

[8] _ Wiener's tests for atomic Markov chains, Illinois J. Math. 12 (1968), 35-56. MR0220355

[9] __ Simple tests for recurrence or transience of infinite sets in random walks on groups., Illinois J. Math. 12 (1968), 439-450. MR0228071

Elizabeth Oldham is Adjunct Assistant Professor, School of Mathematics (and former Lecturer / Senior Lecturer, School of Education) in Trinity College Dublin, the University of Dublin.

School of Mathematics, Trinity College, Dublin

E-mail address: eoldham@tcd.ie 